\title{
PRINSIP AGROEKOSISTEM DALAM KONSERVASI SUMBER DAYA ALAM
}

Oleh :

$\begin{array}{ll}\text { Nama } & : \text { Florensa Octavia Marpaung } \\ \text { Npm } & : 16710003\end{array}$

\section{Pertanian Berwawasan Lingkungan}

Agroekosistem merupakan kesatuan komunitas tumbuhan dan hewan serta lingkungan kimia dan fisikanya yang telah dimodifikasi oleh manusia untuk menghasilkan : makanan, bahan bakar, dan produk lainnya bagi konsumsi kesejahteraan umat manusia. Agroekologi merupakan studi agroekosistem yang holistic, tremasuk semua elemen lingkungan dan manusia. Fokusnya adalah pada bentuk, dinamika dan fungsi hubungan timbal balik antar unsur-unsur tersebut pada proses dimana mereka terlibat. Pada dasarnya harus didasarkan bahwa lingkungan secara luas adalah satu-satunya sebagai dasar atau pondasi bagi usaha pertanian. Dengan demikian tanpa lingkungan yang baik. Lumbanraja (1993) menamai pola pertanian ini untuk daerah pulau samosir dengan istilah Perladangan Selaras Alam yang mana alternatifnya ini untuk daerah tersebut adalah merupakan satu dari berbagai cara yang mungkin dapat dilakukan atas dasar menyadari kondisi alam lingkungan setempat. Selanjutnya Lumbanraja (1997) mengutarakan bahwa konsep pertanian berkelanjutan adalah suatu bentuk pertanian yang berwawasan lingkungan, sebab konsep pertanian berkelanjutan atau yang dikenal dengan istilah sustainable agriculture merupakan suatu pola pertanian yang memelihara daya dukung lingkungan terhadap produksi sepanjang waktu. Pertanian berwawasan lingkungan mempunyai tujuan umum yaitu untuk meningkatkan pendapatan petani yang bersangkutan melalui meningkatan produksi dengan selalu menjaga produktivitas lahan dan lingkungan yang digunakan untuk waktu yang terbatas. 


\section{Uraian Ringkas Prospek Pemanfaatan Lahan Rawa Pasang Surut}

Dari berbagai alternative perluasan yang dapat dilakukan satu diantaranya adalah pembukaan hutan. Dengan memperhatikan hal itu, pembukaan hutan untuk usaha pertanian baru dalam upaya mengganti luas lahan pertanian tanaman pangan yang berkurang sebagai akibat konservasi penggunaan lahan maupun konservasi komoditi sebagaimana diutarakan diatas sebelumnya. Sehingga memperhatikan potensi daerah secara khusus dengan luas lahan rawa yang cukup besar. Pengembangan ini dapat ditempuh dengan pemanfaatan lahan rawa tersebut untuk lahan pertanian baru. Seperti diketahui bahwa pemanfaatan lahan rawa ini untuk menjadi lahan pertanian, memang membutuhkan penanganan yang tepat. Sebagaimana diketahui berbagai kendala pengembangan rawa seperti tata air yang tidak menentu, kadar garam yang tinggi, terbentuknya senyawa-senyawa racun bagi tanaman sebagai akibat dari kondisi tanah yang reduktiv, maupun seringnya ditemui unsur-unsur beracun dalam tanah ini seperti tingginya kadar aluminium tanah dan seringnya dijumpai lapisan tanah yang mengandung pirit. Pertanian pada lahan rawa telah terbukti sangat memberikan keuntungan yang cukup baik untuk berbagai komoditi yang telah dilakukan, mulai dari pengusahaan pertanian lahan basah seperti padi sawah, maupun pertanian tanaman kering seperti berbagai jenis tanama palawija (seperti jagung dan kedelai), tanamana buah-buahan dan sayuran bahkan tanaman industri.

\section{Sistem Pertanian Berkelanjutan ${ }^{(1)}$}

Suatu konsep baru menekan pasokan bahan kimia sekecil mungkin untuk usaha pertanian dalam upaya memproduksi bahan pangan yang cukup dan terus menjaga produktivitas lahan serta mencegah pencemaran lingkungan untuk penggunaan dalam waktu yang tak terbatas (O’ Connell, 1990) dalam Lumbanraja (1997). Richard (1990) dalam Lumbanraja (1997) mengutarakan konsep pertanian baru ini sebagai konsep pertanian berkelanjutan atau yang dikenal dengan istilah sustainable agriculture sesuai dengan istilah yang digunakan oleh Jackson (1980) dan konsep pertanian regenerative dari Rodale (1983) dalam Lumbanraja (1997) yang keduanya merupakan suatu pola pertanian yang berkelanjutan yang memelihara daya dukung lingkungan terhadap produksi sepanjang waktu. 
Keberhasilan pertanian yang berkelanjutan hanya akan tercapai jika masyarakat yang dilibatkan didalamnya sebagai ujung tombak dalam penerapan pola ini harus mampu menerapkan pola pertanian yang berkelanjutan tersebut.

\section{Pertanian Berkelanjutan ${ }^{(2)}$}

Pertanian berkelanjutan adalah pertanian yang menekan pemasokan bahan kimia sedikit mungkin untuk memproduksi bahan pangan yang cukup dan terus menjaga produktivitas lahan serta mencegah pencemaran lingkungan untuk penggunaan dalam waktu yang tidak terbatas (Jackson 1990, O'Connel 1990, Ricahrd 1990) dalam Lumbanraja (2002). Banyak istilah yang digunakan untuk maksud pertanian berkelanjutan seperti pertanian regeneratip (Rodale 1983) dalam Lumbanraja (2002), pertanian masukan rendah (low input agrieulture), pertanian rendah kimia (low ehemical agriculture), pertanian konservasi sumber daya alam dan lingkungan, teknologi pertanian yang efisien sumber daya (Parr et al. 1990) dalam Lumbanraja (2002). Pertanian berkelanjutan bertujuan untuk (1) menjaga dan atau meningkatkan keutuhan sumber daya alam dan melindungi lingkungan, (2) menjamin penghasilan yang tinggi bagi petaninya, (3) mengkonservasi energi, (4) meningkatkan produktivitas, (5) meningkatkan kualitas dan keamanan bahan makanan dan (6) menciptakan keserasian antara pertanian dengan faktor sosial ekonomi lainnya (Parr et al. 1990) dalam Lumbanraja (2002). Dengan demikian, ciri utama pertanian berkelanjutan antara lain adalah (1) kehilangan tanah di bawah atau pada laju kehilangan yang diperbolehkan (tolerable soil loss), (2) mampu meningkatkan pendapatan petani, (3) dapat diterima masyarakat dan (4) mempertahankan kesuburan tanah melalui pendauran bahan organik (Dankelman dan Davidson 1988) dalam Lumbanraja (2002).

\section{Pengaruh Tanaman Interkrop Legum Terhadap Kwalitas Fisik Tanah Pada Lahan Pertanaman Jagung}

Tanaman legum yang digunakan sebagai tanaman sela adalah merupakan campuran dari tanaman alfalfa, clover dan hairy vetch, memberikan pengaruh kumulatif yang nyata (significant) terhadap beberapa sifat fisik untuk kedua tanah 
percobaan. Tanaman sela legum menurunkan berat jenis tanah kering dan menurunkan daya tahan penetrasi tanah dengan nyata. Jika penurunan BD tanah dan penurunan daya tembus (penetrasi) tanah digunakan sebagai tolok ukur maka terbukti bahwa tanaman intercrop legum mampu memperbaiki sifat fisik tanah. Perbaikan sifat fisik tanah ini mungkin merupakan hasil pengaruh dari pertambahan aktivitas akar tanaman dan juga sebagai akibat dari pembenaman (incorporation) sisa tanaman legum ke dalam tanah. Namun terlihat bahwa pengaruh dari tanaman intercrop ini hanya bersifat sementara (transit/ephemeral), tidak terlihat adanya pengaruh yang kumulativ (cumulativ effect). Penambahan pupuk $\mathrm{N}$ pada plot pertanaman jagung saja dapat bermanfaat untuk memperbaiki sifat fisik tanah pada kondisi tanah dan iklim tertentu.

\section{Pertanian Organik}

Pakar pertanian Barat menyebutkan bahwa sistem pertanian organik merupakan hukum pengembalian (law of return) yang berarti suatu sistem yang berusaha untuk mengembalikan semua jenis bahan organik ke dalam tanah, baik dalam bentuk resedu dan limbah pertanaman maupun ternak yang selanjutnya bertujuan memberi makanan pada tanaman. Meskipun sistem pertanian organik dengan segala aspeknya jelas memberikan keuntungan banyak kepada pembangunan pertanian rakyat dan penjagaan lingkungan hidup, termasuk konservasi sumber daya lahan, namun penerapannya tidak mudah dan akan menghadapi banyak kendala.

Empat Prinsip Pertanian organik menurut IFOAM (1972) dalam Lumbanraja (2013):

a. Prinsip Kesehatan:

Pertanian organik harus melestarikan dan meningkatkan kesehatan tanah, tanaman, hewan, manusia dan bumi sebagai satu kesatuan dan tak terpisahkan.

b. Prinsip Ekologi:

Pertanian organik harus didasarkan pada sistem dan siklus ekologi kehidupan. Bekerja, meniru dan berusaha memelihara sistem dan siklus ekologi kehidupan. 
c. Prinsip Keadilan:

Pertanian organik harus membangun hubungan yang mampu menjamin keadilan terkait dengan lingkungan dan kesempatan hidup bersama.

d. Prinsip Perlindungan:

Pertanian organik harus dikelola secara hati-hati dan bertanggungjawab untuk melindungi kesehatan dan kesejahteraan generasi sekarang dan mendatang serta lingkungan hidup.

\section{Degradasi Lahan, Persepsi dan Kepedulian Terhadapnya}

Sebagian besar permukaan bumi kita sudah mengalami degradasi, sebagian sedang mengalami proses degradasi, dan selebihnya berada dalam resiko akan terdegradasi. Degradasi lahan dapat didefenisikan sebagai berkurangnya tatau menurunnya bahkan hilangnya daya guna, ataupun potensi guna, pergantian keanekaragaman atau hilangnya organisme yang tidak dapat digantikan. Secara umum, bahwa degradasi lahan juga dapat berupa penurunan macam alternatif penggunaan suatu lahan atau status penggunaannya. Blaikie \& Brookfield (1987) dalam Lumbanraja (2007) mencoba mengajukan suatu batasan bahwa suatu lahan dinyatakan mengalami degradasi bila lahan tersebut mengalami penurunan/ kemunduran dalam kemampuan dan macam penggunaannya. Chartres dalam (Chisolm \& Dumsday, 1987) dalam Lumbanraja (2007) menyatakan bahwa degradasi lahan akan mungkin diakibatkan suatu faktor atau akibat kombinasi dari berbagai faktor yang mengakibatkan penurunan/pemunduran sifat fisik, sifat kimia ataupun sifat biologi suatu lahan yang mengakibatkan perubahan mendasar pada status penggunaan lahan tersebut hingga penghambatan terhadap penggunaan lahan untuk suatu usaha. Sekali lahan terdegradasi mungkin saja akan dapat dilakukan tindakan rehabilitasi untuk memperbaiki kondisi lahan sampai pada tingkat penggunaan tertentu yang mungkin bisa dicapai. Restorasi lahan mengandung arti sebagai rehabilitasi lahan agar dapat dikembalikan kepada kondisi awalnya sebelum mengalami degradasi. 


\section{DAFTAR PUSTAKA}

Lumbanraja, P. 1994. Pengaruh Tanaman Interkrop Legum Terhadap Kwalitas Fisik Tanah Pada Lahan Pertanaman Jagung. Fakultas Pertanian. Universitas HKBP Nommensen - Medan. Available At: https://www.researchgate.net/publication/327392655_PENGARUH_ TANAMAN_INTERKROP_LEGUM_TERHADAP_KWALITAS_F ISIK_TANAH_PADA_LAHAN_PERTANAMAN_JAGUNG (01 Oktober 2018)

Lumbanraja, P. 1997. Sistem Pertanian Berkelanjutan ${ }^{(1)}$. Diseminarkan pada Seminar Periodik Fakultas Pertanian. Universitas HKBP Nommensen 1997 - Medan. Available At: https://www.researchgate.net/publication/327392671_SISTEM_PER TANIAN_BERKELANJUTAN1 (03 Oktober 2018)

Lumbanraja, P. 2002. Pertanian Berkelanjutan ${ }^{(2)}$. Disampaikan pada seminar nasional tentang "Strategi Pembangunan Berkelanjutan dan Pengelolaan Kawasan Danau Toba" yang diselenggarakan oleh Partungkoan Batak Toba (Parbato) Medan, Yayasan Del Jakarta dan Yayasan Perhimpunan Pencinta Danau Toba pada tanggal 6 April 2002 di Medan. Available At:

https://www.researchgate.net/publication/327392686_Pertanian_Berk elanjutan2 (03 Oktober 2018)

Lumbanraja, P. 2007. Degradasi Lahan (Prospek dan Kepedulian Terhadapnya). Seminar Berkala Fakultas Pertanian, Universitas HKBP Nommensen; Medan 25 Oktober 2007. Universitas HKBP Nommensen - Medan. Available At: https://www.researchgate.net/publication/327392970_DEGRADASI_ LAHAN_persepsi_dan_keperdulian_terhadapnya (02 Oktober 2018) 
Lumbanraja, P. 2011. Uraian Ringakas Prospek Pemanfaatan Lahan Rawa Pasang Surut. Fakultas Pertanian. Universitas HKBP Nommensen - Medan. Available At:

https://www.researchgate.net/publication/327393546_URAIAN_RIN GKAS_PROSPEK_PEMANFAATAN_LAHAN_RAWA_PASANG _SURUT (29 September 2018)

Lumbanraja, P. 2013. Pertanian Berwawasan Lingkungan. Materi Pengabdian Masyarakat Juni. 2013. Di Desa ; Kec. Gunung Meriah; Kab. Deliserdang. Fakultas Pertanian. Universitas HKBP Nommensen Medan. Available At:

https://www.researchgate.net/publication/327393685_PERTANIAN_ BERWAWASAN_LINGKUNGAN (28 September 2018)

Lumbanraja, P. 2013. Pertanian Organik. Materi Pengabdian Masyarakat di Desa Mabar, Kec. Bangun Purba; Deliserdang. Available At: https://www.researchgate.net/publication/327393688_PERTANIAN_ ORGANIK (03 Oktober 2018) 